\title{
Adolescence and the Matter of Prolongation
}

\author{
Arthur Chicralla* \\ Department of Psychology, Universidade Salgado de Oliveira, Brazil
}

*Corresponding author: Arthur Chicralla, Department of Psychology, Universidade Salgado de Oliveira, Brazil, E-mail: a_chicralla@yahoo.com.br

Received: 03 Feb, 2020 | Accepted: 30 Mar, 2020 | Published: 04 Apr, 2020

Citation: Chicralla A (2020) Adolescence and the Matter of Prolongation. J Psychiatry Ment Health 5(1): dx.doi.org/10.16966/2474-7769.135

Copyright: (C) Chicralla A. This is an open-access article distributed under the terms of the Creative Commons Attribution License, which permits unrestricted use, distribution, and reproduction in any medium, provided the original author and source are credited.

This article is based on my master dissertation at State University of Rio de Janeiro, Brazil in which I have investigated the theme of adolescence and the work with adolescents in foster care. This article aims to introduce a perspective on the theme of adolescence and explain why adolescence takes a longer duration nowadays. For this, I present a reflection from sociology and psychoanalysis. In addition to the biological and hormonal issues, there is the psychic aspect linked to the social device. I propose to think of adolescence as a crossing way to the social place of adults with a psychic configuration.

\section{Contribution of Sociology}

According to Le Breton, adolescence is not an event but an issue that cuts across time and space of human societies. Some demarcations vary according to society, whether age, ritual, etc. Therefore, the chronological question is not necessarily defined. The etymological root of the term comes from Latin, adolescere-to grow.

Adolescence only exists in societies that have a margin of time between childhood and the transmission of social responsibilities. In so-called traditional societies, as Le Breton [1] points out, rites of passage eliminate the issue of adolescent transition as the child makes his crossing into adulthood and assumes his role as a man or woman in the community.

In the logic of the rites of passage, social tension tends to be neutralized as well as the anguish of the time to come, as the young man knows the way forward to observe his parents and other older members of his community. Each society uses different criteria to plot the transition to social maturity. In this field-which is diverse-puberty is not necessarily the moment for this identification.

The initiation rites are linked to the radical change in the status and sense of identity of the youth. There is a transformation process that ensures social transmission and unanimous recognition by the group. There is a connection between individual and collective existence. A very present factor in the process of the rite is the corporal inscription through, for example, circumcision, perforation, scraping, waxing, tattooing, excoriation, burn, blow, etc.

Le Breton [1] indicates the rite of passage as the process in which leads to a personal metamorphosis. This operation represents symbolic death and rebirth, the dismissal of the child and the emergence of man or woman. According to this, the context for a society to sustain such rites is articulated with its relationship with the social bond, as the concept of the individual mustn't exist. Given that, collective norms impose themselves on everyone. The subject's body, therefore, does not belong to himself; he is only a member of the collective body. The rites of passage consecrate belonging to gender through precise body marks. They aim to perpetuate the collective plot and the representations and values that support it.

How to think about adolescence specifically in moderns societies, where rituals passage barely exist? How did the notion of adolescence develop? The decline of the ritualistic passage in modern society is the basis for thinking about adolescence today. Moreover, becoming a man or a woman depends more on a personal path which is the hallmark of the feeling of adolescence.

For Le Breton [1], adolescence is not an evident phenomenon in all cultures. It was born in the 18th century in the bourgeois circles from a change of affectivity within families. There was a change in the way couples were formed: no longer only out of financial convenience or tradition but around mutual affection. This mutation in the family accompanies the growing feeling of investment around the child.

Therefore, from this author, we can understand adolescence as a social construction over time, culture and the relationships that make up the social bond.

In this same trajectory, Ariès $\mathrm{P}$ [2] points out that, until the $18^{\text {th }}$ century, adolescence was confused with childhood. Childhood, as a term, was consecrated because it represents the individual's relationship of dependence, the period that precedes his autonomy.

Ariès $\mathrm{P}$, attributes the beginning of adolescence to secondary school education which served the bourgeois population during the $19^{\text {th }}$ century. From that century on, age and school class established a relationship, when age became an essential factor in the demographic structure. Until then, in school life-for example-there was no division of class by age group; the content taught used to bring students together according to interest. Ariès $\mathrm{P}$ [2] points out that birth date records started in Europe around the $16^{\text {th }}$ century, as religious and civil reformers imposed them on the documents starting with the most educated classes. Even after this period, the notion of age itself was treated imprecisely, as it had no bearing on social life. Until the 
$18^{\text {th }}$ century, the feeling of the age of life corresponded more to the social function than to the biological stage; life was divided into welldefined stages regarding activity, physical types, functions, ways of dressing, etc., which were not based on chronological age. According to Ariès $\mathrm{P}$, the beginning of the $20^{\text {th }}$ century already announces through art, especially literature, the way adolescents feel; the author points out that, after the First World War, a collective conscience of youth manifested itself when, for example, the combatants of the battlefront opposed in mass to the old generations in the rear [2].

\section{Contribution of Psychoanalysis}

The second theoretical conception that helps us to understand adolescence is psychoanalysis. To understand the transition from childhood to adulthood, Freud S [3] elaborates on the development of the sexual drive. According to him, the sexual drive is present since childhood, when it is satisfied in the body itself. Freud calls parts of the body that stand out as areas of sexual satisfaction erogenous zones.

Thus, for Freud S [3], the sexual drive during childhood has an auto-erotic character, which means, it is through the body itself that the subject satisfies the drive. For example, the act of breastfeeding in the mother's breast initially entails a need for food and then acquires an independent function of sexual activity, since the pleasure of the act of sucking makes the oral zone a route of sexual satisfaction: experienced pleasure is resumed beyond the organic need for food. Progressively, other areas are noted by the author as condensers for auto-erotic sexual satisfaction.

In this context, the theme of puberty emerges as decisive as the transformations of this stage lead to the passage from auto-erotic sexual life to the search for satisfaction of the genital zone through the encounter with another subject. From puberty, the genital zone, in a perspective of the development of the so-called normal drive assumes a privileged function. This does not mean that infantile libidinal fixations are completely abandoned-they remain a source of satisfaction for the subject. Puberty is however the moment of convocation for the subject to start the sexual encounter. According to Freud S [3], sexual tension and follower pleasure are already experienced in childhood. What only comes at puberty is the experience of the final pleasure or pleasure of satisfying sexual activity [3].

Another important aspect of the puberty stage is a clear definition of male and female characters. Auto-erotic sexual activity is very similar in both sexes and the time of puberty is crucial for the subject to position himself according to the differences of genders. The primacy of the genital zones precipitates identification with the male or female field. Puberty, in addition to configuring the new and final stage of the development of the sexual drive (genital phase), promotes the disconnection of the subject from the authority of the parents. For the subject to be able to start the live encounter, the object-choice of the incestuous primordial fantasy is overcome although the fixation on the incestuous object still has repercussions.

Lacan J [4] takes up the issue of the castration complex. He articulates the notion of the signifier in dialectic between demand and desire. From the beginning, Lacan emphasizes the relevance of castration in Stratifying psychoanalytic symptoms and in the installation of an unconscious position of the subject. He explains that because the subject speaks, his needs suffer a deviation that the subject's demands cannot satisfy. From the gap established between the appetite for satisfaction and the demand for love arises, the instance of desire invades it. The phallus emerges as a privileged signifier of the subject's conjunction with desire.
Lacan's reading of the Freudian Oedipus complex brings the paternal metaphor as the symbolic representation of castration. The subject is located in the dialectic of the desire of other (Lacan's concept) in which the phallus appears as a representation of what is beyond the mother's desire in a point symmetrical to the father. For this reason, there is a development of a psychological system that articulates law and desire [5].

Lacan J, elaborates on the relationship between the advent of puberty and sexuality. According to him, the phallic pleasure reveals the mismatch between the following elements: sense, delight and puberty. The pubescent subject, when launching himself into the otherness as a participant in the contingency of the sexual encounter is faced with the reality of non-relation. What Lacan J aims to demonstrate is that there is no rite or social convention that stably converges enjoyment and meaning. Something remains, which makes this operation inexhaustible [6].

Therefore, the freshness that adolescence brings is the inevitably unsuccessful encounter with the reality of sexuality. The childhood promise of phallic jouissance reveals a taste of disappointment regarding the desired goal which calls the subject to a reconfiguration of fantasy and symptom. Note that this process is not related to the maturation of the biological body nor the subject's chronological development. Adolescence is not without mutations in the pubescent body but the required psychic transformation goes beyond any physical-chemical, hormonal or age apprehension.

Stevens A proposes adolescence as the moment for a variety of possible responses to the emergence of puberty. He elaborates on a precise articulation between puberty and adolescence. The first represents the moment when the non-relationship appears to the subject, it is the emergence of the real characteristic of sexuality. Whereas adolescence is the possible symptomatic response adopted by the subject. Adolescence serves as a metaphor, as it represents the unspeakable absence of sexuality. The symptomatic arrangement of the subject represents a stable attempt to link joy and body [7].

As Stevens A points out, to relate libido and adolescence we must take the reality of puberty as organic as long as we consider the organ not in the hormonal, biological or medical sense but the Lacanian conception: the libido organ as an organ outside the body. Therefore, jouissance has a foreign dimension to the speaking body itself. The libido organ is marked by speech and is not reduced to anatomical modification. Unlike animals, human beings do not have prior knowledge of copulation. The speaking being is not guided by instinct because the operation of constituting the subject from the otherness inaugurates an indelible mark that is not universal [7].

We can consider adolescence as a time to comprehend which means it has the function of the second of the three moments of logical time, as proposed by Lacan J [8]. It is the moment of the process in which the symptomatic rearrangement is determined and a solution is demanded.

There is a plurality of possible responses, although each subject has to find its own path. Biological metamorphoses are the background for the subject to lead their journey and the idea of a solution that is set for everyone is less sustained.

\section{The Prolongation of Adolescence}

Modernity has consequences for both the clinic and the social bond. The new ways of linking civilization with the real, symbolic and imaginary registers transform the way of being a teenager. The brief historical and sociological perspective mentioned above already 
points out to a continuous transformation of this stage; the stability of the concept is apparent.

Psychoanalysis can propose as the constant of adolescence is the demand for a new articulation between enjoyment and the body, starting with the advent of puberty. Therefore, it is worth asking: how to think about the notion of adolescence today? The current scenario can be drawn from the reflection on the decline of tradition, the influence of technologies, etc. I emphasize that we should understand adolescence by the singular path because reaching adulthood demands particular solutions.

According to Miller JA, the rite of passage had a cutting function that was the clear crossing between two stages. However, in today's societies with the decline of tradition, this crossing of initiation loses its meaning, it becomes opaque. As a result, cutting off entry into adulthood tends not to take place or to be extended, generating an indefinite and vague gap, which is precisely what it finds as the characteristic of this stage, as adolescence becomes the failure of puberty metaphor [9].

Stevens A states that; currently, due to the vacillation of the father's function, it is difficult for many young people to make the passage that implies the choice of the new symptom [10].

According to the author, to detach from parental authority, it is necessary to have its symbolic references. Because of the scarcity of paternal countenances, there is an extension of adolescence: the subject is often led to choose a mode of enjoyment that avoids sexual issues, such as drug addiction, anorexia, etc. Adolescence extends as an increasingly vague period, in which the subject evades the call to make his choices, which is why an increasingly intense relationship between adolescence and the world of consumption is observed.

Lacadée P [11]says there is a generalized childish state of mind, in which the subject does not answer for his acts and prefers not to take responsibility for his choices. On the issue of consumption, the author associates the appearance of the object mais-de-gozar with the weakening of the paternal function [12]. It appears, then, that the object of consumption changes the place of ideals without, however, promoting a new ideal. The consequence of this is the short circuit of the otherness of speech: the consumer object brings a subject who submitted to the superego instance is captured by objects that privilege bodily sensations.

The drug, for example, highlighted by Lacadée P, enters the series of possible chosen objects that encode a partnership with the subject. It allows him to replace both auto-erotic and phallic jouissance and to avoid the anguish caused by the emptiness of non-sexual intercourse [11]. Drug addiction guarantees the presence of an object that allows the subject to objectify to the phallic countenance by a new form of a symptom. The subject cuts off his relationship with the others and encloses himself in solitary enjoyment. In other words, in the absence of symbolic references, there is a massive production and consumption of objects that point to a lack of enjoyment, establishing incessant consumption and separating the subject from the otherness.

\section{Conclusion}

To think about adolescence through the phenomenon of prolongation and consumption broadens our field of investigation beyond the age problem. For adolescence concerns a subjective inscription in the transition from childhood to adulthood, related to the symptomatic, phantasmatic and identifiable issue. Thinking about adolescence as a special moment of choices teaches us that every adult carries the mark of that moment, or is alienated in an inconclusive crossing in which, although "adult", something of the adolescent position is maintained unceasingly. What consequences does legislation has that delimits the age of adolescents? On the one hand, it guarantees the passage through adolescence for all, which also implies the obligation to leave it: the subject is legally "Expelled" from adolescence. On the other hand, the legislation does not guarantee the psychic transition effect of this phase, in the sense of updating the object choices and the position of symptoms and fantasies. On the contrary, the chronological delimitation can even confuse the subject in his/her journey in the face of puberty. I do not mean that the age range imposed by the law is irrelevant or unnecessary. For the psychoanalyst, what is important is the singular path of each subject, how the encounter with sexuality occurs and the solution to complete this stage. The encounter between chronological age and adolescence is merely contingent. This fine distinction should guide the psychoanalyst in clinical work.

\section{References}

1. Le Breton D (2017) Uma breve história da adolescência. Belo Horizonte: Editora PUC Minas.

2. Ariès $P(1973)$ História social da criança e da família. $2^{\text {nd }}$ Edition, LTC 2006.

3. Freud S (1905) Três ensaios sobre a teoria da sexualidade. Em: Obras psicológicas completas de Sigmund Freud. $7^{\text {th }}$ Edition, Standard Brasileira.

4. Lacan J (1998) A significação do falo de Lacan. Jorge Zahar.

5. Lacan J, Ribeiro V (1999) O seminário, livro 5: as formações do inconsciente. Jorge Zahar.

6. Lacan J (2003) Prefácio a O despertar da primavera. Em: LACAN J. Outros escritos. Rio de Janeiro, Jorge Zahar.

7. Stevens A (2004) Adolescência, sintoma da puberdade. Em: Curinga. Belo Horizonte: Escola Brasileira de Psicanálise.

8. Lacan J (1945) O tempo lógico e a asserção de certeza antecipada. Em: LACAN J. Escritos. Jorge Zahar.

9. Miller JA (2015) Prólogo" Em: Amadeo De Freda, Damasia. El adolescente actual: nociones clínicas. San Martín: Universidad Nacional de Gral. San Martín. UNSAM EDITA, Fundación CIPAC.

10. Stevens A (2013) Quando a adolescência se prolonga. Em: Opção Lacaniana online nova.

11. Lacadée P (2011) Despertar e o exílio: ensinamentos psicanalíticos: da mais delicada das transições, a adolescência. Contra Capa.

12. Lacan J (2003) Radiofonia. Em: LACAN J. Outros escritos. Rio de Janeiro: Jorge Zahar. 